\title{
RBL1 wt Allele
}

National Cancer Institute

\section{Source}

National Cancer Institute. RBL1 wt Allele. NCI Thesaurus. Code C91747.

Human RBL1 wild-type allele is located in the vicinity of $20 q 11.2$ and is approximately 100 $\mathrm{kb}$ in length. This allele, which encodes retinoblastoma-like protein 1 , is involved in the modulation of cell cycle progression. 